\title{
ANALISIS EFISIENSI PEMASARAN GABAH DAN NILAI TAMBAH BERAS DI KABUPATEN PESAWARAN
}

\author{
(Analysis of the Marketing Efficiency of Paddy and Added Value of Rice in Pesawaran District)
}

Eva Mulia Sari, Ali Ibrahim Hasyim, Suriaty Situmorang

Jurusan Agribisnis, Fakultas Pertanian, Universitas Lampung, Jl. Prof. Dr. Soemantri Brojonegoro No. 1

Bandar Lampung 35145, Telp. 082186933360,e-mail : evamuliasari18@gmail.com

\begin{abstract}
This research aims to analyze the efficiency of paddy marketing system and value added of rice in Pesawaran District. This research was conducted by survey method. The research location is chosen purposively i Kota Jawa Village and Gunung Sari Village, Way Khilau Subdistrict Pesawaran District with consideration that the location is one of the central of paddy production. The samples of this research were 51 paddy farmers who were selected by simple random sampling. The research data was collected in JuneJuly 2017 and analyzed by descriptive and quantitative analysis. The method used in this research is the analysis of the model of S-C-P (structure, conduct, and performance) and used Hayami method to determine the value-added of the rice. The S-C-P model was used to analysis marketing system efficiency. The results showed that paddy marketing system in Pesawaran District was efficient, it could be seen from the producer's share who greater than 50\%. There were three rice milling unit (RMU) in research location and all of that rice miling unit gave a positive value-added to owner.
\end{abstract}

Key words : efficiency, rice, S-C-P models, value-added

\section{PENDAHULUAN}

Tersedianya pangan yang cukup dan berkesinambungan merupakan pilar utama dalam berbagai aspek kehidupan manusia. Di Indonesia, sektor pertanian tanaman pangan memiliki posisi strategis dalam proses penyediaan dalam hal pangan utama nasional, yaitu beras (Kamal, 2011). Hampir 95 persen dari penduduk Indonesia menggunakan beras sebagai pangan pokok, bahkan sebagai food habit, sehingga masyarakat beranggapan bahwa belum dikatakan makan jika belum makan nasi (Nurmala 1998).

Peran beras selain sebagai pangan pokok, juga berperan dalam penyediaan kesempatan kerja, sehingga dapat memberikan sumbangan pendapatan bagi para pelaku usahatani padi. Selanjutnya, sebagai salah satu dari komoditas tanaman pangan, padi atau beras memiliki peran lain, yaitu pemenuhan kebutuhan gizi bagi tubuh manusia. Padi memiliki kandungan karbohidrat yang sangat tinggi, dimana fungsi karbohidrat menurut Tejasari (2005) adalah sebagai penyedia energi utama bagi tubuh manusia.

Salah satu sentra produksi padi di Indonesia adalah Provinsi Lampung dan Kabupaten Pesawaran merupakan salah satu daerah di Provinsi Lampung yang memiliki produksi dan luas panen padi tertinggi dibandingkan dengan komoditas tanaman pangan yang ada di daerah tersebut. Tahun 2014, produksi padi di Kabupaten Pesawaran mencapai 164.386 ton dengan luas panen seluas 31.748 ha (Badan Pusat Statistik Kabupaten Pesawaran, 2015).

Kabupaten Pesawaran memiliki daerah-daerah yang berperan sebagai penyumbang produksi padi, salah satunya adalah Kecamatan Way Khilau. Berdasarkan data BPS tahun 2015, produktivitas tanaman padi sawah di Kecamatan Way Khilau tahun 2014 adalah yang tertinggi di Kabupaten Pesawaran serta mengalami peningkatan luas lahan dan produksi dari tahun sebelumnya, yaitu meningkat seluas $6,43 \%$ dan produksinya meningkat sebesar $4,75 \%$. Peningkatan produksi padi di Kecamatan Way Khilau ini nyatanya tidak terlalu memberi dampak terhadap pendapatan yang diterima petani padi, karena petani padi di Kecamatan Way Khilau memiliki kebiasaan menjual gabah hasil panennya dalam keadaan basah atau dalam bentuk gabah kering panen (GKP), sehingga harga yang diterima petani produsen pun lebih rendah jika dibandingkan dengan menjualnya dalam keadaan kering atau dalam bentuk gabah kering giling (GKG).

Padi merupakan produk strategis sehingga harus dilakukan tanam serentak. Hal ini menyebabkan 
produksi padi pada saat musim panen akan terus mengalami peningkatan, sedangkan permintaan cenderung tetap atau berkembang dengan laju yang tidak terlalu tinggi, sehingga harga pun akan mengalami penurunan. Masalah yang dominan dihadapi petani mengenai rendahnya harga yang diterima petani, disebabkan oleh kebiasaan petani yang menjual padi dalam bentuk gabah kering panen (GKP). Padahal, jika petani mampu menahan produksi padinya dan menjual dalam keadaan kering (GKG) atau bahkan melakukan pengolahan lebih lanjut (seperti halnya menjual kepada konsumen dalam bentuk beras), tentulah petani akan memperoleh nilai tambah dari pascapanen atau pengolahan yang dilakukan.

Pada kenyataannya, kegiatan pengolahan ini dilakukan oleh pemilik pabrik penggilingan di daerah tersebut, sehingga nilai tambahnya dinikmati oleh pemilik pabrik. Dengan kata lain, agar petani dapat menikmati nilai tambah dari pemasaran padi, maka kendala mengenai kebiasaan petani dalam menjual gabah dalam bentuk gabah kering panen (GKP) harus diatasi dan sistem pemasaran harus diperbaiki. Oleh sebab itu, diperlukan penelitian mengenai efisiensi pemasaran gabah dan nilai tambah beras di Kabupaten Pesawaran. Berdasarkan uraian tersebut, maka tujuan penelitian ini adalah untuk menganalisis efisiensi sistem pemasaran gabah di Kabupaten Pesawaran dan untuk mengetahui nilai tambah yang diperoleh dari pengolahan gabah menjadi beras di Kabupaten Pesawaran.

\section{METODE PENELITIAN}

Penelitian ini dilaksanakan di Kecamatan Way Khilau Kabupten Pesawaran, yaitu di Desa Kota Jawa dan Desa Gunung Sari. Pemilihan lokasi penelitian dilakukan secara sengaja (purposive) dengan pertimbangan bahwa desa tersebut merupakan sentra produksi padi dari sepuluh desa yang ada di Kecamatan Way Khilau. Metode penelitian yang digunakan adalah metode survai, sedangkan data yang dikumpulkan adalah data primer dan data sekunder. Sampel dari penelitian ini adalah 51 petani padi yang dipilih menggunakan sampel acak sederhana Pengumpulan data dilakukan pada bulan Juni-Juli 2017. Metode analisis yang digunakan untuk mengetahui efisiensi pemasaran, adalah model SC-P (structure, conduct, performance) yang dikenal dengan pendekatan organisasi pasar (Hasyim, 2012). Pada dasarnya organisasi pasar dikelompokkan menjadi 3 (tiga) komponen, yaitu:
1. Struktur pasar (market structure), yang meliputi:

a. Jumlah lembaga pemasaran

b. Diferensiasi produk

c. Kondisi keluar masuk pasar

2. Perilaku pasar (market conduct), yang meliputi:
a. Sistem penentuan harga dan praktik transaksi
b. Sistem pembayaran

3. Keragaan pasar (market performance), yang meliputi :
a. Saluran pemasaran
b. Harga, biaya dan volume jual beli
c. Pangsa produsen (producer's share)
d. Marjin pemasaran dan rasio profit marjin (RPM)

Struktur pasar, prilaku pasar dan saluran pemasaran serta harga, biaya dan volume jual beli dianalisis secara deskriptif kualitatif, sedangkan pangsa produsen dan marjin pemasaran serta rasio profit marjin (RPM) dianalisis secara kuantitatif. Analisis pangsa produsen memiliki tujuan untuk mengetahui bagian harga yang diterima oleh petani (produsen). Pangsa produsen yang tinggi, menunjukkan kinerja pasar yang semakin baik dilihat dari sisi produsen. Menurut Hasibuan (1993), pangsa produsen dirumuskan sebagai:

$\mathrm{PS}=\frac{\mathrm{Pf}}{\operatorname{Pr}} \times 100 \%$

Keterangan :

$\mathrm{PS}=$ Bagian harga padi yang diterima oleh petani (pangsa produsen)

$\mathrm{Pf}=$ Harga padi di tingkat petani (produsen)

$\operatorname{Pr}=$ Harga padi di tingkat konsumen akhir

Marjin pemasaran adalah selisih harga di tingkat konsumen dengan harga di tingkat produsen. Perhitungan marjin pemasaran dan rasio marjin keuntungan secara matematis menurut Hasyim (2012), dapat ditulis sebagai:

mji $=$ Psi-Pbi

atau

$\mathrm{mji}=\mathrm{bti}-\pi \mathrm{i}$

Total marjin pemasaran adalah :

$\mathrm{Mj}=\sum_{\mathrm{i}=1}^{\mathrm{n}} \mathrm{mji}$

atau 
$\mathrm{Mj}-\mathrm{Pr}=\mathrm{Pf}$

Menurut Hasyim (2012), rasio profit marjin (rasio marjin keuntungan) dapat dinyatakan sebagai :

$\mathrm{RPM}=\frac{\pi \mathrm{i}}{\mathrm{bti}}$

Keterangan :

$\mathrm{Mj}=$ Total marjin pemasaran $(\mathrm{Rp} / \mathrm{kg})$

Psi $=$ Harga jual lembaga pemasaran tingkat ke-i (Rp)

$\mathrm{Pbi}=$ Harga beli lembaga pemasaran tingkat ke-i (Rp)

bti $=$ Harga total lembaga pemasaran tinggkat ke-i (Rp)

$\pi \mathrm{i}=$ Keuntungan lembaga pemasaran tingkat $\mathrm{ke}-\mathrm{i}(\mathrm{Rp} / \mathrm{kg})$

$\mathrm{i}=1,2,3, \ldots \mathrm{n}$

$\mathrm{mji}=$ Marjin pemasaran tingkat ke-i $(\mathrm{Rp} / \mathrm{kg})$

$\operatorname{Pr}=$ Harga pada tingkat konsumen akhir $(\mathrm{Rp} / \mathrm{kg})$

Pf $=$ Harga pada tingkat petani $(\mathrm{Rp} / \mathrm{kg})$.

Perhitungan nilai tambah gabah menjadi beras pada pabrik penggilingan yang ada di Kecamatan Way Khilau dilakukan dengan menggunakan metode Hayami (disajikan pada Tabel 2).

\section{HASIL DAN PEMBAHASAN}

\section{Analisis Efisiensi Pemasaran Gabah}

Berdasarkan analisis struktur pasar, prilaku pasar dan keragaan pasar (SCP) diketahui bahwa:

\section{Struktur pasar}

Struktur pasar yang ada di daerah penelitian diidentifikasi melalui jumlah lembaga pemasaran yang terlibat, diferensiasi produk dan hambatan keluar masuk pasar. Melalui penelusuran dengan mengikuti alur pemasaran dari 51 orang petani sampel di Desa Kota Jawa dan Gunung Sari, diketahui bahwa terdapat 3 orang pedagang pengumpul tingkat desa, 2 orang pedagang pengumpul tingkat kecamatan dan 3 orang yang bertindak sebagai pemilik pabrik penggilingan padi. Uraian mengenai struktur pasar yang dihadapi oleh setiap lembaga pemasaran gabah di Kecamatan Way Khilau adalah

a. Petani

Struktur pasar yang dihadapi oleh petani mengarah pada pasar oligopsoni, karena jumlah penjual (petani produsen) lebih banyak dari jumlah pembeli (pedagang pengumpul desa, pedagang pengumpul kecamatan, pabrik penggilingan padi). Komoditas yang diperjualbelikan bersifat homogen, yaitu gabah kering panen (GKP). Dalam upaya keluar masuk pasar, petani sebagai penjual gabah bebas keluar masuk pasar dan juga dapat dengan mudah memasarkan gabah hasil panennya kepada para pembeli. Informasi pasar diperoleh dari sesama petani maupun melalui survai kepada pedagang pengumpul desa, pengumpul kecamatan dan pabrik penggilingan padi di desa tersebut.

b. Pedagang pengumpul tingkat desa

Struktur pasar yang dihadapi oleh pedagang pengumpul tingkat desa adalah pasar oligopoli, karena jumlah penjual (pengumpul desa) lebih sedikit dari jumlah pembeli (pabrik penggilingan padi di luar kabupaten). Hambatan masuk pasar yang dihadapi oleh pedagang pengumpul desa adalah mengenai kepemilikan modal, sehingga masyarakat di Kecamatan Way Khilau tidak dapat dengan mudah menjadi pedagang pengumpul desa di daerah tersebut. Komoditas yang diperjualbelikan bersifat homogen, yaitu gabah kering panen (GKP). Informasi pasar diperoleh pengumpul desa dari pengumpul kecamatan dan juga pabrik penggilingan.

c. Pedagang pengumpul tingkat kecamatan

Struktur pasar yang dihadapi oleh pedagang pengumpul kecamatan adalah pasar oligopoli, dimana jumlah penjual (pengumpul kecamatan) lebih sedikit dari jumlah pembeli (pabrik penggilingan padi di luar provinsi). Hambatan keluar masuk pasar yang dihadapi pengumpul kecamatan adalah pada modal yang harus dikeluarkan untuk membeli gabah, sehingga masyarakat tidak dapat dengan mudah menjadi pedagang pengumpul kecamatan. Informasi pasar diperoleh pengumpul kecamatan dari pabrik penggilingan yang menjadi tujuan penjualan gabah mereka.

d. Pabrik penggilingan padi

Struktur pasar yang dihadapi oleh pabrik penggilingan padi di Kecamatan Way 
Khilau adalah oligopoli, karena jumlah penjual (pabrik penggilingan) lebih sedikit dari pada jumlah pembeli (pedagang pengecer beras dan masyarakat). Hambatan masuk pasar yang harus dihadapi oleh pemilik pabrik penggilingan juga berhubungan dengan kepemilikan atas modal, dimana untuk menjadi seorang pemilik pabrik di sebuah desa harus memiliki modal usaha yang cukup besar. Hal ini yang menyebabkan jumlah pemilik pabrik yang ada di daerah penelitian hanya sedikit.

Struktur pasar pada penelitian kali ini berbeda dengan hasil penelitian yang dilakukan oleh Haryani (2013). Perbedaan tersebut dapat dilihat dari sisi hambatan keluar masuk pasar dan juga informasi pasar yang diterima petani. Petani pada penelitian sebelumnya mengalami hambatan karena kurangnya modal dalam berusahatani, sehingga berpengaruh terhadap pendapatan dan produktivitas. Selain itu informasi mengenai harga yang diterima petani juga kurang. Sedangkan pada penelitian kali ini, petani dapat dengan mudah untuk memasuki pasar, petani bisa dengan mudah menjual gabah yang dihasilkan kepada pembeli. Mengenai informasi harga gabah, sebagian dari petani melakukan survai dan kemudian menjualnya ke pengumpul ataupun pabrik penggilingan, sedangkan hambatan keluar masuk pasar yang dihadapi lembaga perantara adalah sama, yaitu kurangnya modal usaha.

\section{Perilaku pasar}

Perilaku pasar dapat diketahui dengan melihat beberapa kegiatan yang dilakukan oleh lembaga pemasaran, di antaranya

a. Sistem penentuan harga dan praktik transaksi

Penetapan harga pasar gabah di tingkat petani ditentukan oleh pembeli (pengumpul desa, pengumpul kecamatan dan pabrik penggilingan), sedangkan pengumpul desa menetapkan harga gabah berdasarkan informasi yang diperoleh dari pabrik penggilingan dan juga pengumpul kecamatan. Di sisi lain, pedagang pengumpul kecamatan menetapkan harga beli gabah berdasarkan informasi harga yang diperoleh dari pabrik penggilingan di luar Provinsi Lampung (Serang). Dimana pabrik penggilingan yang ada di Kota Serang merupakan salah satu pabrik yang menjadi tujuan penjualan gabah oleh pedagang pengumpul kecamatan yang memiliki skala pembelian dan penjualan gabah yang cukup besar. Oleh sebab itu harga gabah yang diterima lembaga perantara akan lebih tinggi dibandingkan jika menjual gabah ke pabrik penggilingan yang ada di daerah Lampung. Dengan demikian, lembaga perantara juga dapat menetapkan harga gabah yang lebih tinggi bagi petani, sehingga hal tersebut dapat menjadi strategi dalam melakukan persaingan pasar.

Hasil penelitian ini berbeda dengan penelitian yang dilakukan oleh Dewi (2017). Hasil penelitian Dewi (2017) tersebut menyebutkan bahwa di dua desa yang menjadi lokasi penelitiannya memiliki sistem penetapan harga padi yang berbeda, dimana petani di Desa Bunga Raya dapat melakukan kegiatan tawar menawar dengan para pedagang, sedangkan di Desa Kemuning, karena mayoritas petani terikat dengan pedagang besar maka petani harus menerima harga yang telah ditetapkan oleh pedagang besar yang ada. Pada penelitian kali ini, para petani tidak memiliki keterikatan dengan para pedagang sehingga petani dapat melakukan tawar-menawar dengan harga awal ditetapkan oleh lembaga pemasaran yang lebih tinggi.

b. Sistem pembayaran

Sistem pembayaran yang diterima oleh petani sebagai penjual adalah sistem pembayaran secara tunai, persekot dan tunda bayar. Dari tiga lembaga perantara yang ada, pedagang pengumpul kecamatan dan pabrik penggilingan melakukan sistem pembayaran secara tunai, sedangkan pedagang pengumpul desa menggunakan sistem pembayaran secara tunai, persekot dan juga tunda bayar. Hal ini disebabkan oleh pedagang pengumpul desa yang pada dasarnya memiliki modal relatif lebih kecil dari pedagang pengumpul kecamatan dan juga pabrik penggilingan. Selanjutnya sistem pembayaran yang diberikan pabrik penggilingan kepada pedagang pengumpul 
desa dan pengumpul kecamatan adalah secara tunai.

Sistem pembayaran yang diterima oleh petani pada penelitian ini, tidak jauh berbeda dengan penelitian yang dilakukan oleh Aditama (2011). Sistem pembayaran yang diterima petani pada penelitian Aditama (2011) merupakan sistem pembayaran secara tunai dan tunda bayar, namun tidak ada yang melakukan pembayaran persekot. Pada penelitian ini sistem pembayaran yang diterima petani selain secara tunai dan juga tunda bayar, terdapat sistem pembayaran secara persekot, dimana pembeli memberikan uang jaminan kepada petani kemudian sisa pembayarannya dilakukan setelah gabah tersebut terjual.

\section{Keragaan pasar}

a. Saluran pemasaran

Berdasarkan data hasil penelitian diketahui bahwa saluran pemasaran gabah di Kecamatan Way Khilau ada 4 macam, yaitu:

(1) Petani $\longrightarrow$ Pedagang pengumpul desa Pabrik $\rightarrow$ Penggilingan padi di luar Kabupaten Pesawaran (di Pringsewu)

(2) Petani $\longrightarrow$ Pedagang pengumpul kecamatan $\longrightarrow$ Pabrik penggilingan padi di luar Kabupaten Pesawaran (di Pringsewu)

(3) Petani $\longrightarrow$ Pedagang pengumpul kecamatan $\longrightarrow$ Pabrik penggilingan padi di luar Provinsi Lampung (di Serang)

(4) Petani $\longrightarrow$ Pabrik penggilingan padi di Kecamatan Way Khilau (di Pesawaran).

Secara skematis pola saluran pemasaran gabah yang ada di Kecamatan Way Khilau disajikan pada Gambar 1.

Dari 4 pola pemasaran tersebut, petani produsen lebih banyak $(49,02 \%)$ menjual hasil panennya kepada pedagang pengumpul tingkat kecamatan, sisanya sebagian $(19,61 \%)$ petani menjual gabahnya ke pengumpul tingkat desa dan ke penggilingan padi yang ada di desa penelitian $(31,37 \%)$.

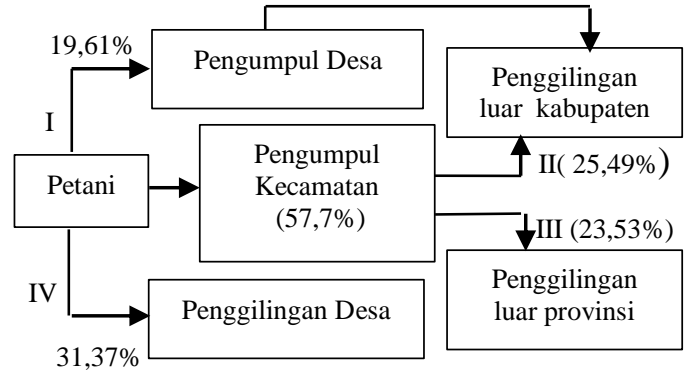

Gambar 1. Saluran pemasaran gabah di Kecamatan Way Khilau tahun 2017

Penelitian ini sedikit berbeda dengan penelitian Manggopa (2013). Dimana pada penelitian Manggopa (2013) terdapat tiga saluran pemasaran yang terbentuk. Saluran yang paling efisien adalah saluran pemasaran II yaitu petani menjual hasil produksi nanas ke pedagang pengecer kemudian pedagang pengecer menjualnya kembali ke konsumen.

b. Harga, biaya dan volume pembelian

Rata-rata harga yang diterima oleh petani di setiap saluran berbeda-beda. Pada saluran I petani yang menjual gabahnya ke pengumpul desa menerima harga sebesar Rp 3.920,00,- per kg. Saluran II petani menerima harga dari pengumpul kecamatan sebesar Rp 4.023,08,- per kg. Pada saluran III petani menerima harga dari pengumpul kecamatan sebesar Rp 3.983,33,- per kg. Saluran IV, harga gabah yang diterima petani dari pabrik penggilingan adalah $\mathrm{Rp}$ $3.955,56,-$ per $\mathrm{kg}$. Pada dasarnya harga yang ditawarkan oleh masing-masing saluran tidak jauh berbeda, namun saluran II tetap menawarkan harga gabah yang paling tinggi. Hal tersebut disebabkan oleh pedagang pengumpul kecamatan memiliki kapasitas pembelian gabah yang cukup besar, yaitu 800 ton dalam satu kali musim panen.

Biaya pasca panen yang dikeluarkan petani dalam upaya memasarkan gabah hanya sebatas biaya transportasi dari sawah ke pinggiran jalan, sedangkan biaya yang dikeluakan oleh pedagang pengumpul desa, pedagang pengumpul kecamatan dan juga pabrik penggilingan di antaranya adalah biaya angkut dan bongkar muat gabah, biaya kemasan, biaya tenaga kerja dan juga 
biaya penyusutan. Adapun besarnya persentase biaya pemasaran yang dikeluarkan oleh pedagang pengumpul desa pada saluran I adalah 10,23 persen, pada saluran II sebesar 10,60 persen sedangkan pada saluran III biaya pemasaran yang dikeluarkan pengumpul kecamatan adalah yang tertinggi yaitu sebesar 15,25 persen. Hal ini terjadi karena lokasi penjualan gabah pada saluran III adalah diluar Provinsi Lampung (di Kota Serang) sehingga memerlukan biaya transportasi yang lebih tinggi.

c. Analisis marjin pemasaran, rasio profit marjin (RPM) dan pangsa produsen (Producer's share)

Marjin pemasaran adalah selisih harga di tingkat konsumen dengan harga di tingkat petani produsen. Pangsa produsen (producer's share) adalah bagian harga yang dibayar konsumen akhir yang dapat dinikmati oleh petani produsen, dinyatakan dalam persentase (Hasibuan, 1993). Pangsa produsen yang tinggi menunjukkan kinerja pasar yang semakin baik. Dengan kata lain, semakin tinggi pangsa produsen, maka semakin efisien sistem pemasaran. , Disisi lain, nilai rasio profit marjin (RPM) yang relatif menyebar merata di berbagai tingkat lembaga pemasaran adalah cerminan mengenai sistem pemasaran yang efisien. Selanjutnya, jika selisih RPM antar lembaga pemasaran sama dengan nol, maka pemasaran dapat dikatakan efisien. Analisis pangsa produsen, marjin pemasaran dan rasio profit marjin (RPM) pada saluran pemasaran di Kecamatan Way Khilau disajikan pada Tabel 1.

Tabel 1. Sebaran pangsa produsen, marjin pemasaran dan rasio profit marjin gabah di Kecamatan Way Khilau, tahun 2017

\begin{tabular}{|c|c|c|c|c|c|}
\hline Saluran & $\begin{array}{c}\mathrm{Pf} \\
(\mathrm{Rp} / \mathrm{kg})\end{array}$ & $\begin{array}{c}\mathrm{Pr} \\
(\mathrm{Rp} / \mathrm{kg})\end{array}$ & $\begin{array}{c}\mathrm{Mj} \\
(\mathrm{Rp} / \mathrm{kg})\end{array}$ & $\begin{array}{l}\mathrm{RPM} \\
(\%)\end{array}$ & $\begin{array}{l}\text { PS } \\
(\%)\end{array}$ \\
\hline I & $3.920,00$ & 4.36 & 67 & 100 & 86 \\
\hline II & 4. & & & & \\
\hline III & 3. & & & & \\
\hline IV & 3.95 & & 0 & 0 & 00 \\
\hline \multicolumn{6}{|c|}{ Keterangan : } \\
\hline $\mathrm{Pf}$ & \multicolumn{5}{|c|}{ Harga gabah di tingkat petani produsen $(\mathrm{Rp} / \mathrm{kg})$} \\
\hline $\operatorname{Pr}$ & \multicolumn{5}{|c|}{$\begin{array}{l}\text { Harga gabah di tingkat pembeli akhir (lembaga } \\
\text { perantara) }(\mathrm{Rp} / \mathrm{kg})\end{array}$} \\
\hline 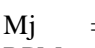 & \multicolumn{5}{|c|}{$\begin{array}{l}\text { perantara) }(\mathrm{K} p / \mathrm{kg}) \\
\text { Total marjin pemasaran (=Pr-Pf) }(\mathrm{Rp} / \mathrm{kg})\end{array}$} \\
\hline PM & \multicolumn{5}{|c|}{ Rasio profit marjin (\%) } \\
\hline
\end{tabular}

PS = Bagian harga yang diterima oleh petani produsen $(\%)$

Berdasarkan Tabel 1 diketahui bahwa harga gabah yang diterima oleh masing-masing petani tidak jauh berbeda. Jika dilakukan pengurangan antara harga gabah yang diterima lembaga perantara dan petani, maka akan menghasilkan nilai marjin pemasaran. Nilai marjin pemasaran yang tertinggi terdapat pada saluran III, dimana petani menjual gabahnya secara langsung kepada pedagang pengumpul kecamatan, kemudian dijual kembali ke pabrik penggilingan di luar Provinsi Lampung (di Kota Serang). Sedangkan pada saluran IV, tidak terdapat marjin dari pemasaran yang dilakukan karena petani menjual gabahnya secara langsung ke pabrik penggilingan tanpa adanya lembaga perantara, sehingga marjin pemasaran adalah $\mathrm{Rp} 0$. Ratio profit margin (RPM) pada setiap saluran menyebar tidak merata yang menggambarkan adanya kesenjangan tingkat kepuasan diantara lembaga pemasaran yang ada.

Producer share yang diperoleh setiap lembaga pemasaran berada di atas $80 \%$, yaitu $82 \%$ $100 \%$. Saluran IV adalah saluran pemasaran terpendek dan memiliki pangsa produsen paling tinggi karena petani menjual gabahnya secara langsung ke pabrik penggilingan tanpa adanya perantara. Hal ini membuktikan bahwa semakin pendek saluran pemasaran, maka akan semakin kecil nilai marjin pemasaran yang terbentuk, sehingga hal tersebut dapat meningkatkan bagian harga yang diterima oleh petani sebagai produsen (producer share) di daerah tersebut.

Penelitian ini tidak jauh berbeda dengan penelitian yang dilakukan oleh Anggraeni, Hasyim dan Situmorang (2013). Petani menjual hasil panennya langsung ke pabrik tapioka tanpa melalui perantara. Sehingga marjin pemasaran pada saluran pemasaran tersebut sama dengan nol dan share yang diperoleh petani sebesar $100 \%$.

\section{Analisis Nilai Tambah}

Metode yang digunakan untuk mengetahui besarnya nilai tambah dari pengolahan gabah adalah metode Hayami. Tabel 2 menyajikan nilai tambah dari proses pengolahan gabah menjadi beras di Kecamatan Way Khilau, tahun 2017. 
Tabel 2. Sebaran nilai tambah pengolahan gabah kering panen (GKP) menjadi beras pada pabrik penggilingan padi di Kecamatan Way Khilau, tahun 2017

\begin{tabular}{|c|c|c|c|c|c|c|}
\hline \multirow[t]{2}{*}{ No } & Variabel & Nilai & Satuan & \multicolumn{3}{|c|}{ Nilai } \\
\hline & \multicolumn{3}{|c|}{ Output, input dan harga } & A & $\mathrm{B}$ & $\mathrm{C}$ \\
\hline 1. & Jumlah output & A & $\mathrm{Kg}$ & $52.440,0000$ & $230.640,0000$ & $85.500,0000$ \\
\hline 2. & Jumlah input & $\mathrm{B}$ & $\mathrm{Kg}$ & $92.000,0000$ & $400.000,0000$ & $150.000,0000$ \\
\hline 3. & Jumlah tenaga kerja & $\mathrm{C}$ & HOK & 282,2857 & $1.086,0000$ & 277,7143 \\
\hline 4. & Faktor konversi & $\mathrm{D}=\mathrm{A} / \mathrm{B}$ & & 0,5700 & 0,5766 & 0,5700 \\
\hline 5. & Koefisien tenaga kerja & $\mathrm{E}=\mathrm{C} / \mathrm{B}$ & $\mathrm{HOK} / \mathrm{kg}$ & 0,0031 & 0,0027 & 0,0019 \\
\hline 6. & Harga output & $\mathrm{F}$ & $\mathrm{Rp} / \mathrm{kg}$ & $8.400,0000$ & $8.400,0000$ & $8.000,0000$ \\
\hline 7. & Upah tenaga kerja & G & $\mathrm{Rp} / \mathrm{HOK}$ & $75.000,0000$ & $80.000,0000$ & $80.000,0000$ \\
\hline \multicolumn{7}{|c|}{ Pendapatan dan keuntungan } \\
\hline 8. & Harga input yang digunakan & $\mathrm{H}$ & $\mathrm{Rp} / \mathrm{kg}$ & $3.950,0000$ & $3.916,6700$ & $4.000,0000$ \\
\hline 9. & Sumbangan input lain & I & $\mathrm{Rp} / \mathrm{kg}$ & 26,1549 & 21,5703 & 23,0000 \\
\hline 10. & Nilai output & $\mathrm{J}=\mathrm{D} \times \mathrm{F}$ & $\mathrm{Rp} / \mathrm{kg}$ & $4.788,0000$ & $4.843,4400$ & $4.560,0000$ \\
\hline 11. & Nilai tambah & $\mathrm{K}=\mathrm{J}-\mathrm{I}-\mathrm{H}$ & $\mathrm{Rp} / \mathrm{kg}$ & 811,8451 & 905,1997 & 537,0000 \\
\hline 12. & Rasio nilai tambah & $\mathrm{L}=(\mathrm{K} / \mathrm{J}) \times 100 \%$ & $\%$ & 16,9558 & 18,6892 & 11,7763 \\
\hline 13. & Imbalan tenaga kerja & $\mathrm{M}=\mathrm{E} \times \mathrm{G}$ & $\mathrm{Rp} / \mathrm{kg}$ & 230,1242 & 217,2000 & 148,1143 \\
\hline 14. & Bagian tenaga kerja & $\mathrm{N} \%=(\mathrm{M} / \mathrm{K}) \times 100 \%$ & $\%$ & 28,3458 & 23,9947 & 27,5818 \\
\hline 15. & Keuntungan & $\mathrm{O}=\mathrm{K}-\mathrm{M}$ & $\mathrm{Rp} / \mathrm{kg}$ & 581,7209 & 687,9997 & 388,8857 \\
\hline 16. & Tingkat keuntungan & $\mathrm{P} \%=(\mathrm{O} / \mathrm{K}) \times 100 \%$ & $\%$ & 71,6542 & 76,0053 & 72,4182 \\
\hline \multicolumn{7}{|c|}{ Balas jasa } \\
\hline 17. & Marjin keuntungan & $\mathrm{Q}=\mathrm{J}-\mathrm{H}$ & $\mathrm{Rp} / \mathrm{kg}$ & 838,0000 & 926,7700 & 560,0000 \\
\hline 18. & Persentase tenaga kerja & $\mathrm{R}=(\mathrm{M} / \mathrm{Q}) \times 100 \%$ & $\%$ & 27,4611 & 23,4362 & 26,4490 \\
\hline 19. & Input lain & $S=(I / Q) \times 100 \%$ & $\%$ & 3,1211 & 2,3275 & 4,1071 \\
\hline 20. & Keuntungan pemilik & $\mathrm{T}=(\mathrm{O} / \mathrm{Q}) \times 100 \%$ & $\%$ & 69,4178 & 74,2363 & 69,4439 \\
\hline
\end{tabular}

Keterangan :

$\mathrm{A}=$ Pabrik penggilingan milik Bapak Nahzori

$\mathrm{B}=$ Pabrik penggilingan milik Bapak H.M. Zaenuddin

$\mathrm{C}=$ Pabrik penggilingan milik Bapak Kasam

Berdasarkan Tabel 2 diketahui bahwa nilai ratarata dari pengolahan $1 \mathrm{~kg}$ gabah kering panen (GKP) pada masing-masing penggilingan menghasilkan $0,57 \mathrm{~kg}$ beras. Nilai konversi ini menunjukkan adanya penyusutan gabah pada saat proses pengolahan, di antaranya penyusutan akibat penjemuran dan penyusutan akibat proses penggilingan. Nilai tambah dari masing-masing pabrik penggilingan berbeda-beda, namun tetap memberikan nilai positif karena lebih besar dari 0 . Artinya, kegiatan pengolahan gabah menjadi beras pada masing-masing pabrik penggilingan memberikan keuntungan bagi setiap pemilik.

Dari tiga pabrik penggilingan di daerah penelitian, pabrik yang memperoleh nilai tambah tertinggi adalah pabrik penggilingan $B$, yaitu milik H.M.
Zaenuddin. Besarnya nilai tambah tersebut disebabkan oleh harga output yang tinggi dan rendahnya harga input produksi, sehingga mempengaruhi besarnya nilai marjin keuntungan yang diterima pabrik penggilingan $B$, yaitu sebesar Rp926,77 per kg. Selain itu, karena pemilik pabrik memiliki pengalaman yang cukup lama dalam mengelola pabrik penggilang, maka hal tersebut memberikan dampak positif terhadap nilai tambah yang diterima pemilik pabrik penggilingan $\mathrm{B}$. Berbeda dengan pabrik penggilingan $\mathrm{C}$ yang memperoleh marjin keuntungan paling rendah, yaitu sebesar Rp560,00 per kg. Rendahnya marjin keuntungan tersebut dipengaruhi oleh harga jual pabrik penggilingan $\mathrm{C}$ yang juga rendah yaitu sebesar Rp8.000,00 per kg. Selanjutnya pada pabrik penggilingan $\mathrm{A}$, marjin keuntungan yang 
diperoleh pabrik penggilingan tidak jauh berbeda dengan yang diterima oleh penggilingan $\mathrm{C}$, yaitu sebesar Rp838,00 per kg.

Hasil penelitian ini berbeda dengan penelitian yang dilakukan oleh Syahputri (2016) yang menghitung nilai tambah dari pengolahan gabah kering panen menjadi gabah kering giling, kemudian barulah dihitung nilai tambah gabah kering giling menjadi beras. Besarnya nilai tambah pengolahan gabah kering panen menjadi gabah kering giling adalah sebesar Rp40,73 per $\mathrm{kg}$, sedangkan nilai tambah pengolahan gabah kering giling menjadi beras adalah Rp770,42 per $\mathrm{kg}$, sehingga total nilai tambah yang diperoleh sebesar Rp811,15 per kg. Hal ini tentu berbeda dengan penelitian yang dilakukan kali ini, yang hanya menghitung nilai tambah dari pengolahan gabah kering panen langsung menjadi beras. oleh sebab itu besarnya nilai tambah pun berbeda-beda.

\section{KESIMPULAN}

Berdasarkan hasil dan pembahasan dari penelitian yang telah dilakukan, maka dapat disimpulkan bahwa sistem pemasaran gabah di Kabupaten Pesawaran sudah efisien dilihat dari pangsa produsen $(\geq 80 \%)$ walaupun cenderung mengarah ke pasar persaingan tidak sempurna (oligopsoni), perilaku pasar menggambarkan bahwa hambatan masuk keluar pasar dialami oleh lembaga perantara dalam permodalan serta rasio profit marjin yang relatif tidak merata. Kegiatan pengolahan gabah (GKP) menjadi beras pada tiga pabrik penggilingan padi yang ada di Kabupaten Pesawaran memberikan nilai tambah positif, artinya kegiatan pengolahan yang dilakukan oleh tiga pabrik tersebut memberikan keuntungan bagi setiap pemilik pabrik.

\section{DAFTAR PUSTAKA}

Aditama P. 2011. Analisis Tataniaga Beras di Desa Kenduren, Kecamatan Wedung Kabupaten Demak. Skripsi. Departemen Agribisnis Fakultas Ekonomi dan Manajemen Institut Pertanian Bogor. https://docslide.org/ analisis-tataniaga-beras-di-desa-kenduren-ke camatan-wedung-kabupaten-demak.
Anggraeni N, Hasyim AI, dan Situmorang S. 2013. Analisis Pemasaran Ubi Kayu di Provinsi Lampung. JIIA, 1 (1): 84 http://jurnal.fp. unila.ac.id/index.php/JIA/article/view/135. [30 April 2016].

Badan Pusat Statistik Kabupaten Pesawaran. 2015. Kabupaten Pesawaran dalam Angka. Badan Pusat Statistik. Lampung.

Dewi N. 2017. Analisis Struktur, Prilaku dan Kinerja Pasar Komoditas Padi di Desa Bunga Raya dan di Desa Kemuning Muda Kecamatan Bunga Raya Kabupaten Siak. Jurnal Ilmu Agribisnis, 19 (1): 50. https://ejurnal.unilak.ac.id/index.php/agr/articl e/view/736/465. [16 Desember 2017].

Hasibuan N.1993. Ekonomi Industri: Persaingan, Monopoli dan Regulasi. LP3ES. Jakarta.

Hasyim AI. 2012. Tataniaga Pertanian. Universitas Lampung. Bandar Lampung.

Haryani D. 2013. Kajian Analisis Margin Pemasaran dan Integrasi Pasar Gabah/Beras di Provinsi Banten. Balai Pengkajian Teknologi Pertanian Banten. https:// www.researchgate.net/publication/285590986 . [16 Desember 2017].

Kamal M. 2011. Kajian Strategi Pemanfaatan Cahaya dan Nitrogen dalam Produksi Tanaman Pangan. Bandar Lampung: Universitas Lampung.

Manggopa CJ. 3013. Efisiensi Pemasaran Nanas di Desa Lobong Kecamatan Passi Barat Bolang Mongondow. Jurnal Universitas Negeri Gorontalo. http://docplayer.info/317 76685-Jurnal-efisiensi-pemasaran-nanas-di-d esa-lobong-kecamatan-passi-barat-kabupat enbolaang-mongondow-chrisandi-jordan-mang gopa.html. [14 Agustus 2017].

Nurmala T. 1998. Serelia (Sumber Karbohidrat Utama). Rineka Cipta. Jakarta.

Syahputri IRA. 2016. Efisiensi Biaya Produksi dan Nilai Tambah Gabah pada Unit Processing dan Produksi Beras Organik Tani Mandiri I di Desa Lombok Kulon Kecamatan Wonosari. Skripsi. Program Studi Agribisnis Fakultas Pertanian Universitas Jember. Jember. http://repository.unej.ac.id/handle/123456789/ 78495. [10 Desember 2017].

Tejasari. 2005. Nilai Gizi Pangan. Graha Ilmu. Yogyakarta. 